\title{
Study of Saving and Credit Mobile Application Model and Empowering the Poor
}

\author{
Margareta Wahyu Catur Wijayanti ${ }^{1}$
}

Wahana Visi Indonesia - Indonesia

\begin{abstract}
This study tries to describe how an application, called ASCA (Accumulating Saving \& Credit Association) developed its mobile application on the Android platform for empowering the poor. Microfinance which has an important role in alleviating poverty, reducing income inequality and increasing economic growth. Community access to the formal financial system is only $52 \%$ of the total population, informal $31 \%$ and $17 \%$ of the population experience exclusivity unable to access the financial system. Based on the high level of poverty and the low access of the public to the financial system, WVI developed a savings group model, which is ASCA. Build upon monitoring and focused discussion, the ASCA model proves to be a learning tool for the poor to save money, be disciplined to manage family finances, build good character of the borrower and change behavior in spending money. The application overcomes the weaknesses of manual recording, builds a transparent and independent information system, as well as records good financial footprint.
\end{abstract}

Keywords: digital application, savings and loans, poverty, financial access

\footnotetext{
${ }^{1}$ Margareta Wahyu C.Wijayanti, Economic specialists and family resilience at Wahana Visi Indonesia (Social Humanitarian Organization)
} 


\title{
Kajian Penggunaan Aplikasi Simpan Pinjam dan Pemberdayaan Masyarakat Miskin
}

\author{
Margareta Wahyu Catur Wijayanti
}

\section{Latar Belakang}

Kemiskinan dipandang sebagai ketidakmampuan dari sisi ekonomi untuk memenuhi kebutuhan dasar makanan dan bukan makanan yang diukur dari sisi pengeluaran. Dengan demikian penduduk miskin adalah penduduk yang memiliki rata-rata pengeluaran per kapita per bulan di bawah garis kemiskinan (GK). Pada semester II 2017, nilai GK nasional adalah Rp 400.995,00/kapita/bulan untuk wilayah perkotaan dan Rp 370.910,00/kapita/bulan untuk wilayah perdesaan. Dengan ambang batas tersebut, jumlah penduduk miskin sampai semester II 2017 adalah sebesar 25,68 juta orang atau 10,12\% (BPS, 2018).

Banyak penelitian di dunia menunjukkan bahwa keterlibatan sektor keuangan (financial inclusion) mempunyai peran penting dalam pengentasan kemiskinan, mengurangi perbedaan pendapatan dan meningkatkan pertumbuhan ekonomi (Doi, 2014). CGAP dan Bank Dunia (2010) menyatakan bahwa di Indonesia, secara nasional akses ke sistem keuangan formal hanya menjangkau sekitar 52\% dari total penduduk. Di sisi lain, terdapat 31\% penduduk mengakses keuangan informal dan $17 \%$ penduduk yang mengalami ekslusifitas tidak mengakses sistem keuangan (Rakhmindyarto \& Syaifullah, 2014).

Dengan kondisi kemiskinan tersebut, seseorang yang tidak mempunyai akses ke sistem keuangan (misalnya: buruh bangunan, yang mempunyai gaji mingguan dan tidak mempunyai rekening bank) akan sulit untuk menyisihkan pendapatannya, akan kehilangan kesempatan untuk mengembangkan uang yang disimpannya dan juga menanggung resiko kecurian, kehilangan uangnya karena kebakaran atau sebab lain dan pada akhirnya tidak mempunyai dana cadangan saat terjadi resiko kehidupan seperti sakit, kematian anggota keluarga, bencana, dll.

Andalan yang dimiliki oleh masyarakat miskin maupun pengusaha mikro yang tidak mempunyai akses ke lembaga keuangan saat situasi darurat adalah para pelepas uang. Dengan nilai pinjaman Rp 100.000,00 uang yang diterima oleh peminjam adalah Rp 90.000,00 - Rp 95.000,00. Cicilan pinjaman dilakukan keesokan harinya dengan cicilan pinjaman sebesar Rp 3.000,00 selama 40 hari atau 
Rp 4.000,00 selama 30 hari. Total yang dibayarkan peminjam adalah Rp 120.000,00. Dengan demikian, bunga pinjaman yang dibayar oleh peminjam berkisar 30-35\% selama masa pinjaman 30 atau 40 hari. Beban bunga pinjaman yang sangat besar (FGD dengan masyarakat, 2015).

Masalah lain yang dialami masyarakat miskin adalah ketidakmampuannya melakukan/membangun tabungan. Lembaga keuangan yang berjarak jauh, penyisihan pendapatan harian yang terlalu kecil, syarat-syarat administrasi dan proses catat mencatat yang harus dipenuhi, menjadi alasan masyarakat malas menabung di lembaga keuangan formal. Bila kemudian masyarakat dapat menabung, maka bentuk tabungannya adalah tunai di rumah atau benda (ternak, perhiasan, hasil panen, dsb). Tabungan di rumah dalam bentuk tunai ataupun benda berharga, rentan akan kerusakan, kehilangan atau terlalu mudah untuk dibelanjakan sehingga fungsi tabungan sebagai sarana perlindungan tidak tercapai.

Financial inclusion menjadi salah satu strategi pemerintah untuk mengatasi masalah kemiskinan dan meningkatkan akses masyarakat kepada lembaga keuangan diantaranya melalui mekanisme pemberian langsung tunai ataupun pemberian kredit. Beberapa contoh program keuangan mikro diantaranya: 1. Tim Nasional Percepatan Penanggulangan Kemiskinan (TNP2K) mengembangkan Simpanan Keluarga Sejahtera yaitu bantuan langsung nontunai dari pemerintah ke rekening simpanan rumah tangga sasaran menggunakan sistem Layanan Keuangan Digital/LKD. (TN2PK, 2014)

2. Pemerintah Propinsi DKI Jakarta, mengembangkan Koperasi Jasa Keuangan (KJK) Pemberdayaan Ekonomi Masyarakat Kelurahan (PEMK), dengan memberikan dukungan dana bergulir setiap KJK di setiap kelurahan adalah sebesar Rp 1,2 Milyar. Dengan total KJK sebanyak 267 KJK, sampai dengan November 2015, hanya 20 KJK yang bisa berjalan baik dan melaksanakan fungsinya (Berita Jakarta, 2015).

3. Program Kredit Usaha Rakyat (KUR). Sampai dengan 7 April 2016, realisasi penyaluran KUR baru mencapai Rp 31 triliun atau 25,8\% dari target 2016 sebesar Rp 120 triliun (Antara, 2016).

Contoh-contoh di atas menunjukkan bahwa upaya pengentasan kemiskinan menjadi target utama pemerintah dengan keuangan mikro menjadi salah satu medianya. Melalui bantuan langsung tunai ataupun pemberian kredit, pemerintah berharap kemiskinan tertanggulangi karena masyarakat miskin melakukan kredit 
usaha sehingga mendapat tambahan pendapatan serta masyarakat membangun tabungan dengan menyisakan uang di rekeningnya. Harapan pemerintah tersebut jarang tercapai karena kurangnya tanggung jawab masyarakat sehubungan uangnya adalah uang program dan bukan masyarakat sendiri.

Didasarkan kondisi di atas, diperlukan upaya meningkatkan ketahanan masyarakat miskin dengan membangun tabungan dari kepunyaan masyarakat miskin sendiri, karena orang miskin bukanlah orang yang tidak mempunyai apa-apa, namun hanya mempunyai aset yang sedikit atau terbatas. Dengan mengumpulkan aset terbatas antar orang miskin dan melakukan kerjasama dan kemudian mengembangkannya dalam pinjaman untuk akses modal, telah menjadikan masyarakat mempunyai kemampuan memberdayakan dirinya sendiri. Kemampuan menabung masyarakat miskin juga terbukti meningkat sehingga ketahanan keluarga juga semakin kuat.

Di Indonesia, pendekatan menabung terlebih dahulu baru kemudian melakukan pinjaman dilakukan oleh koperasi kredit yang di tingkat nasional berada dalam koordinasi Induk Koperasi Kredit (Inkopdit) dimana sampai dengan akhir 2016 jumlah koperasi yang dikoordinasi mencapai 914 koperasi, dengan anggota mencapai 2.731 .242 orang dan aset yang mencapai lebih dari 25 trilyun. Ini menjadi model nyata penghimpunan kemandirian masyarakat.

Masalah lain yang ditemui dalam program financial inclusion untuk masyarakat miskin adalah ketiadaan jaminan fisik untuk mengakses dana secara mandiri kepada lembaga keuangan mikro (LKM) formal baik bank maupun koperasi (Cucoindo, 2018). Sehingga walaupun Koperasi Kredit (Kopdit) adalah contoh nyata kemandirian masyarakat, namun tetap saja sulit diakses oleh masyarakat miskin.

Memanfaatkan perkembangan teknologi dan kemudahan akses informasi, maka sistem informasi dengan aplikasi yang mudah dan murah yang pengelolaannya bisa dilakukan oleh masyarakat miskin sendiri mutlak diperlukan. Data dalam aplikasi yang transparan merupakan cermin kinerja kelompok dan rekam jejak anggota yang bisa dimanfaatkan untuk pengganti jaminan fisik saat mengakses LKM formal.

Didasarkan dengan kondisi tersebut Yayasan Wahana Visi Indonesia (WVI), sejak 2011 mengembangkan kelompok simpan pinjam model ASKA (Asosiasi Simpan pinjam untuk Kesejahteraan Anak). Sebuah pendekatan untuk menjawab setiap masalah yang ditemui oleh masyarakat miskin dalam mengelola uang keluarganya maupun akses kepada sumber daya modal. 


\section{Metodologi}

Dalam mengembangkan kelompok simpan pinjam model ASKA dilakukan melalui beberapa tahapan yaitu :

\subsection{Penumbuhan Kelompok}

Penumbuhan kelompok simpan pinjam model ASKA dilakukan melalui beberapa tahapan yaitu: 1) Identifikasi masalah dan harapan masyarakat miskin, 2) Sosialisasi pendekatan kelompok simpan pinjam ASKA, 3) Pelatihan teknis pengelolaan kelompok dan 4) Pertemuan membangun kesepakatan internal kelompok meliputi aturan pengelolaan kelompok, aturan teknis simpanan, pinjaman, penggunaan dana sosial maupun pemilihan tim pengelola. Waktu yang dibutuhkan untuk proses ini kurang lebih 4 minggu.

\subsection{Pendampingan Kelompok}

Pendampingan kelompok dilakukan melalui kehadiran pendamping dalam pertemuan kelompok. Pendampingan secara intensif dilakukan pada 3-4 kali pertemuan pertama sampai saat kelompok memberikan pinjaman dan 2 kali saat pertemuan kelompok menjelang siklus kelompok berakhir.

\subsection{Monitoring Kelompok}

Monitoring rutin kelompok dilakukan dengan menggunakan aplikasi ASKA berbasis android. Aplikasi ini didukung oleh PT. Accenture Indonesia yang membangun aplikasi ini secara pro bono. Aplikasi dibuat oleh PT. Accenture secara pro bono, karena PT. Accenture tertarik dengan konsep kelompok ASKA yang sungguh mengubah perilaku masyarakat dan mendukung program pemerintah dalam memperluas financial inclusion.

Semua orang yang sudah menjadi anggota ASKA dapat memanfaatkan aplikasi yang sudah terbangun ini. Target pemanfaat aplikasi ini selanjutnya adalah LKM formal (bank dan non bank) dan lembaga asuransi.

Input data informasi dilakukan secara mandiri oleh kelompok setiap kali mereka selesai melakukan pertemuan. Input data kelompok meliputi aturan kelompok, pengelola kelompok, aturan kelompok, transaksi keuangan yang meliputi dana sosial, saham (tabungan) maupun pinjaman.

Proses pembelajaran dilakukan secara rutin, minimal 1 tahun sekali di tiap wilayah dampingan dengan melakukan diskusi terfokus maupun dengan 
menggunakan metode plus minus interesting (PMI).

\section{HASIL PROGRAM}

\subsection{Kelompok ASKA}

Kelompok ASKA dapat dikembangkan untuk mengorganisir masyarakat yang tidak mempunyai akses pada LKM formal, terutama di kantong-kantong kemiskinan, baik di perkotaan maupun perdesaan. Kelompok dapat dibentuk untuk orang dewasa atau anak-anak, untuk laki-laki maupun perempuan. Kelompok dapat menjadi kelompok terpisah antara laki-laki-perempuan, terpisah antara dewasaanak-anak atau merupakan kelompok campuran. Pengelompokan disesuaikan dengan kebutuhan masyarakat.

Setelah kelompok berproses dan mengalami perubahan perilaku dalam menabung, meminjam serta membangun dana sosial, maka kelompok dapat dihubungkan dengan LKM formal baik bank maupun non bank, serta lembaga asuransi. Bank dan atau non bank untuk melayani perluasan dan peningkatan tabungan dan pinjaman masyarakat, sedangkan lembaga asuransi untuk perlindungan anggota (masyarakat) dari resiko kehidupan (kematian, kecelakaan, bencana alam maupun bencana sosial) yang lebih besar dibandingkan yang dibutuhkan kelompok.

Kelompok Simpan Pinjam Model ASKA, diadopsi dari model ASCA (Accumulating Saving and Credit Assosiation), model yang dikembangkan oleh VSL Assosiates (www.vsla.net). Di Indonesia, nama ASCA dirubah menjadi ASKA yaitu Asosiasi Simpan pinjam untuk Kesejahteraan Anak.

Kelompok ASKA dikembangkan dengan landasan memenuhi kebutuhan masyarakat miskin yaitu mengelola arus kas keluarga, tersedianya dana cepat saat kondisi darurat, keamanan atas uang yang dikumpulkannya dan juga pengembangan nilai dari uang yang dikumpulkannya. Sistem pengelolaan yang transparan dari simpan pinjam model ASKA ini, juga menjawab ketakutan masyarakat miskin akan hilangnya uang mereka karena ketidakjujuran pengelola ataupun anggota kelompok.

\subsubsection{Sistem Pengelolaan Kelompok ASKA}

Dalam mengelola kelompok simpan pinjam model ASKA, digunakan prinsip dan ciri-ciri sebagai berikut:

- Kelompok ASKA bersifat otonom dan dikelola sendiri untuk memastikan kemandirian lembaga keuangan. 
- Keanggotaan kelompok terbatas antara 10-25 orang untuk memastikan rentang kendali pengelolaan kelompok.

- Satu siklus tabungan dan pinjaman terbatas waktu yaitu antara 9-12 bulan.

- Tabungan dilakukan dalam bentuk saham.

- Saham diinvestasikan dalam bentuk pinjaman anggota dengan jangka waktu pinjaman tertentu dengan memberikan jasa kepada kelompok.

- Dalam satu siklus, saham dikembalikan kepada anggota dengan proporsi pembagian didasarkan pada besaran saham.

- Setiap anggota mempunyai buku anggota individual untuk memastikan jumlah saham dan merunut jumlah pinjaman.

- Anggota diseleksi oleh anggota sendiri sehingga terjadi penguatan dalam kelompok.

- Anggota wajib hadir di pertemuan kelompok.

- Pertemuan kelompok rutin dilakukan dengan frekuensi yang tetap, misalnya seminggu sekali, setiap 10 hari sekali, dua minggu sekali atau sebulan sekali.

- Kelompok memberikan penghargaan bagi anggota yang paling rentan (miskin), dengan menetapkan harga saham sesuai dengan kemampuan anggota yang paling rentan (miskin). Prakteknya di Indonesia, nilai saham @Rp 10.000,00 Rp 25.000,00.

- Pengelolaan kelompok sangat transparan, karena menggunakan kotak besi berkunci 3 untuk menyimpan seluruh uang dan buku tabungan anggota, dimana kunci dipegang oleh 3 orang yang berbeda. Pembukaan kotak hanya untuk aktivitas simpan pinjam dan dilakukan saat pertemuan di depan seluruh anggota.

- Kedisiplinan kelompok terbangun dengan baik karena tata kelola kelompok dibangun, disepakati dan dihidupi sendiri oleh anggota. Mekanisme membangun disiplin dilakukan dengan membuat aturan denda yang besarannya disepakati seluruh anggota.

- Membangun dana sosial yang merupakan dana yang dapat dipakai untuk kondisi darurat terutama untuk jaminan kesehatan dan pendidikan.

- Pembatasan keanggotaan dan masa bertugas pengelola, menjadikan kelompok selalu berada dalam rentang kendali yang optimal dan transfer ketrampilan yang terus menerus antara anggota satu dengan lainnya.

- Kepastian mendapatkan keuntungan, karena setiap tahun, seluruh saham (tabungan) dibagikan kembali kepada anggota beserta dengan pengembangannya. 
Berikut adalah gambar alat-alat yang digunakan oleh Kelompok Simpan Pinjam Model ASKA dalam melakukan aktivitasnya.

Gambar 1. Gambar Kotak dan Alat Tulis Kelompok Simpan Pinjam Model ASKA
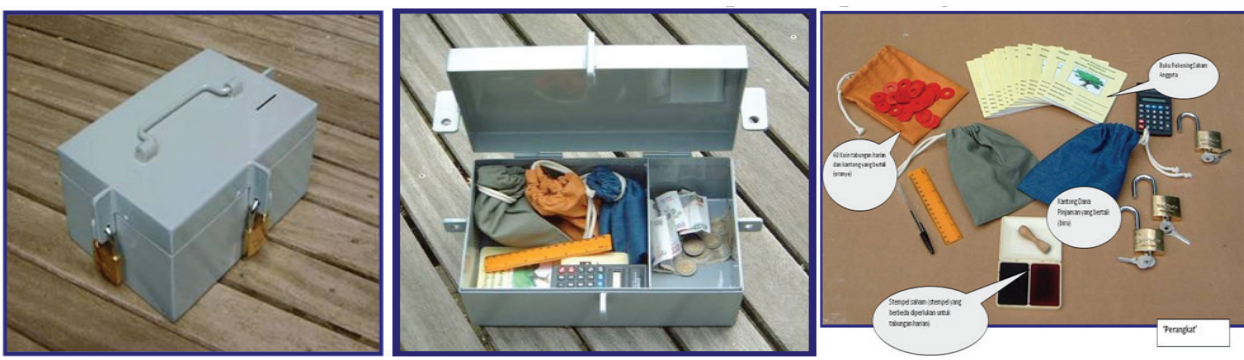

\subsubsection{Bukti Keberhasilan Kelompok Model ASKA}

Dalam masa pendampingan oleh Yayasan Wahana Visi Indonesia (WVI) selama 6 tahun ini perkembangan kelompok ASKA nyata terjadi. Dari awalnya hanya di Jakarta, saat ini kelompok model ASKA berkembang di Surabaya (Jawa Timur), Palu, Kabupaten Sigi, Parigi Motong dan Tojo Una Una/Touna (Sulawesi Tengah), Kabupaten Kolaka dan Kolaka Timur (Sulawesi Tenggara), Kabupaten Pinrang dan Enrekang (Sulawesi Selatan) serta Kabupaten Halmahera Utara (Maluku Utara). Untuk wilayah Jakarta Utara dan Jakarta Timur, dari awalnya 5 kelompok di tahun 2012, saat ini jumlah kelompok mencapai 66 kelompok dengan aset yang dikumpulkan oleh anggota lebih dari 3 milyar rupiah.

Grafik 1. dan Grafik 2. di bawah ini menunjukkan tentang perkembangan kelompok dan anggota kelompok dari tahun 2012 - 2016. Pada awalnya, tidak banyak masyarakat miskin yang mau bergabung dari kelompok. Alasan utamanya adalah ketakutan bahwa uang mereka yang hilang. Alasan lainnya adalah ketidakpercayaan diri bahwa mereka mampu menabung di tengah keterbatasan mereka secara ekonomi.

Grafik 1. Total Kelompok Model ASKA di Jakarta Timur \& Utara

\section{Total Kelompok}

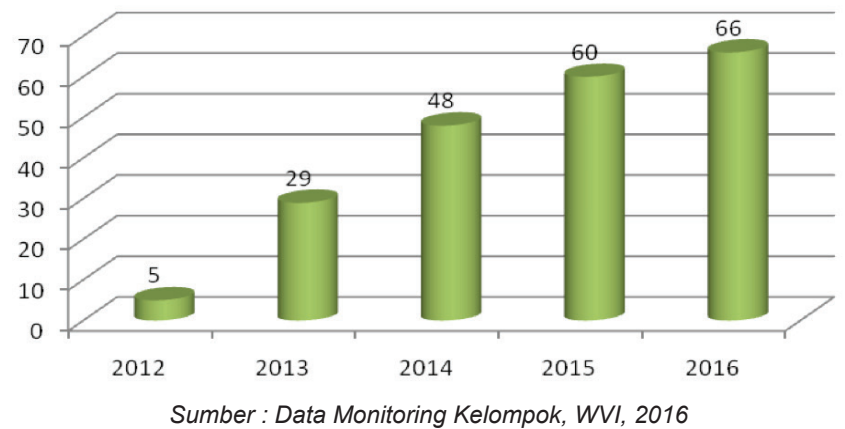


Saat kelompok-kelompok awal menutup siklusnya pada akhir tahun pertama, terjadi perubahan pandangan anggota. Ketakutan mereka akan kemungkinan uang mereka hilang dan ketidakpercayaan diri akan kemampuan menabung, seluruhnya tidak terbukti. Bahkan mereka menjadi semakin percaya diri karena bisa membangun menabung, berdisiplin dengan aturan kelompok dan melakukan pinjaman serta membayar pinjaman tepat waktu. Usaha mikro yang mereka geluti sebagai sumber utama pendapatan juga meningkat karena modal usaha mereka berkembang, lebih giat berusaha dan mengelola keuangan keluarga mereka. Membangun tabungan yang lebih banyak ternyata menjadi pemacu motivasi untuk hidup lebih sejahtera terutama bagi masa depan anak-anak mereka.

Grafik 2. Data Total Anggota Kelompok Model ASKA di Jakarta Timur dan Utara

\section{Total Anggota}

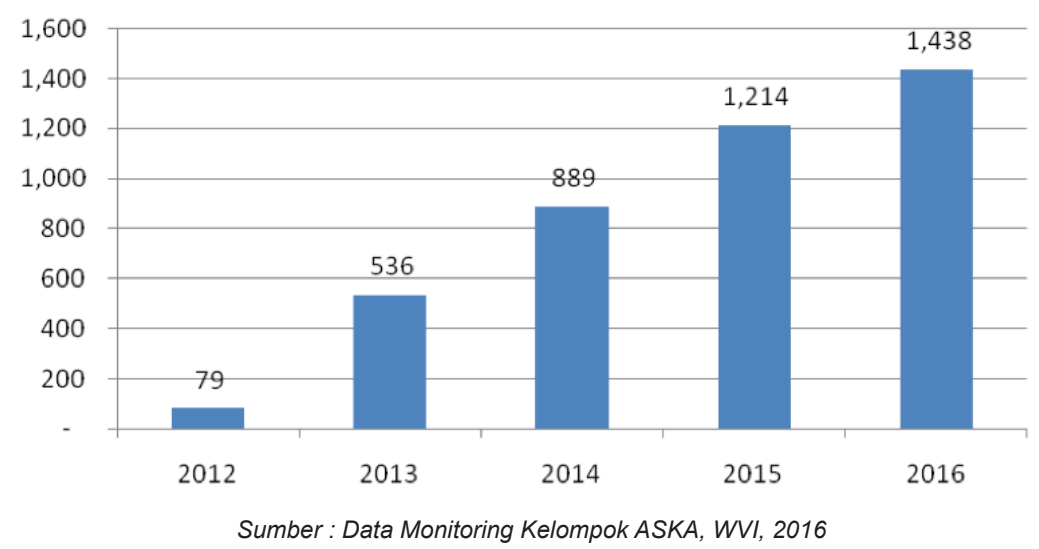

Perubahan motivasi dari kelompok-kelompok awal, ternyata memicu mereka untuk menularkannya kepada masyarakat sekitarnya. Dan merekalah yang menjadi agen-agen perubahan tersebut. Dalam 6 tahun, di Jakarta saja, diawali dengan 79 orang yang tergabung dalam kelompok model ASKA, sampai akhir 2016 sudah 1.438 orang yang bergabung menjadi anggota kelompok.

Perubahan perilaku menabung juga ditunjukkan anggota kelompok ASKA. Saat kepercayaan anggota belum sepenuhnya, nilai satu satuan saham hanya berkisar Rp 5.000,00 - 10.000,00. Pembelian saham setiap pertemuan juga relatif kecil hanya 1-2 saham/orang/pertemuan, namun saat kepercayaan diri dan kepercayaan terhadap kelompok semakin tinggi, semakin tinggi pula kemampuan menabung anggota. Saat ini, kelompok yang sudah lebih dari 2 siklus, kemampuan anggota membeli saham adalah maksimal yaitu di 5 saham/anggota/pertemuan. Nilai saham juga meningkat, walaupun tidak sangat tinggi, karena setiap kelompok 
tetap menggunakan prinsip, pembatasnya adalah kemampuan anggota yang paling miskin di kelompoknya. Saat ini nilai tertinggi per saham adalah $\mathrm{Rp} 25.000,00$. Jasa pinjaman yang diterapkan di kelompok ASKA cukup tinggi apabila dibandingkan dengan kredit mikro di sekitar lingkungan masyarakat miskin, akan tetapi tetap lebih rendah apabila dibandingkan dengan pelepas uang/renternir. Jasa pinjaman berkisar antara 2\%/bulan tetap - 10\%/3 bulan tetap. Jangka waktu pinjaman 3 bulan. Walaupun jasa pinjaman relatif tinggi, namun anggota tidak berkeberatan karena jasa pinjaman yang dikumpulkan selama satu siklus akan kembali ke anggota melalui mekanisme peningkatan nilai saham pada akhir siklus.

Grafik 3. Nilai Tabungan Anggota \& Perkembangannya 2014-2016 (Juta Rupiah)

\section{NILAITABUNGAN ANGGOTA \& PENGEMBANGANNYA}

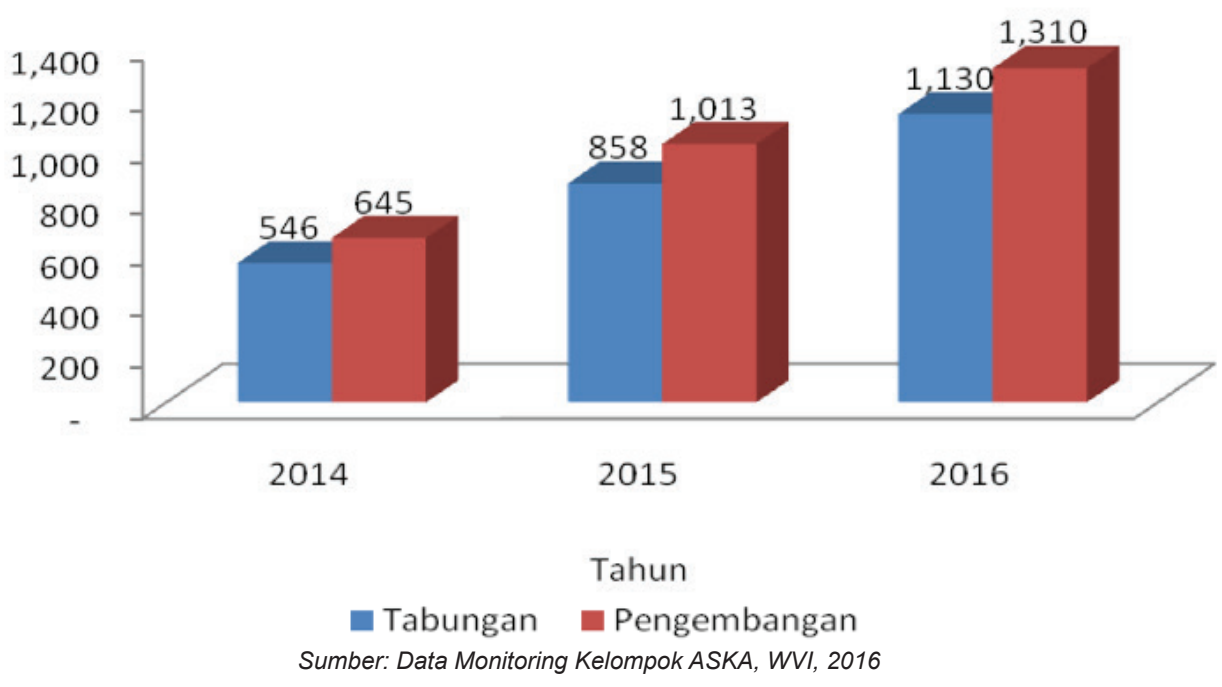

Grafik 3 di atas menunjukkan nilai tabungan dan perkembangannya dari tahun 2014-2016. Kenaikan pengembangan saham berkisar antara 16-18\% per tahun, sehingga semisal nilai saham pada awal siklus Rp 10.000,00 pada akhir siklus sudah menjadiRp11.800,00. Jauhlebihtinggidibandingkanbilauangditabung diLKMformal.

Dengan nilai tabungan yang mencapai Rp 1,3 Milyar untuk tahun 2016, maka rata-rata nilai tabungan per anggota mencapai $\mathrm{Rp}$ 915.000/orang/tahun. Dengan rata-rata jumlah pertemuan $2 \mathrm{x}$ sebulan, maka setiap pertemuan, anggota dapat menabung Rp 40.000,00 atau Rp 80.000,00/bulan. Pencapaian tabungan yang sangat luar biasa untuk anggota yang pada umumnya masyarakat miskin di Jakarta Utara dan Timur dan sebelumnya sama sekali tidak mempunyai tabungan, bahkan terlilit hutang dari pelepas uang. 
Grafik 4. Perkembangan jumlah kelompok, anggota dan aset kelompok ASKA 2015-2016

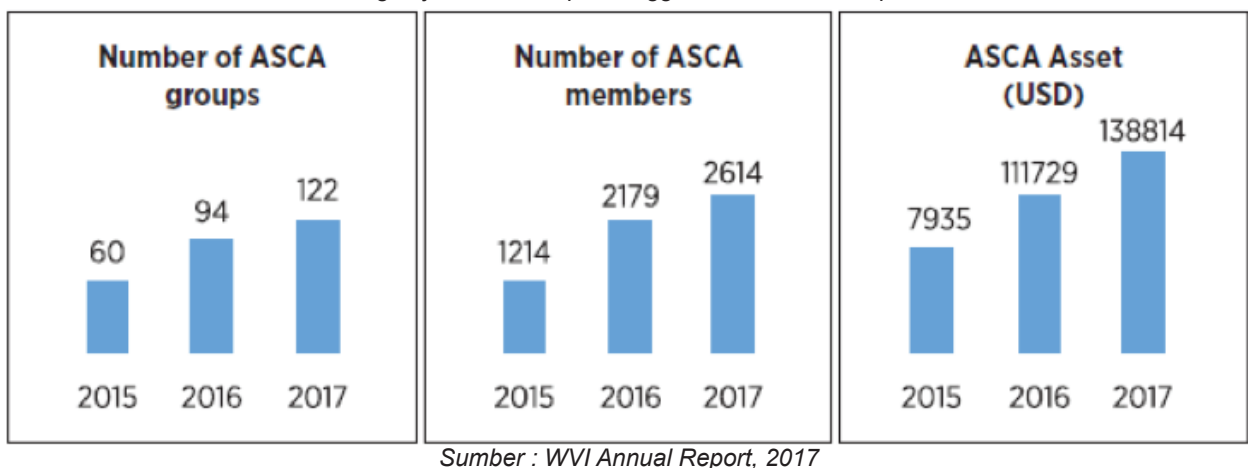

Kemampuan anggota untuk mengakses modal dengan melakukan pinjaman kepada kelompok juga meningkat sejalan dengan tabungan yang dibangunnya. Pinjaman yang bisa diakses adalah $2 \mathrm{x}$ dari nilai tabungan. Saat ini, beberapa kelompok sudah mampu memberikan pinjaman sampai dengan Rp 4.000.000,00. Pemanfaatan pinjaman terutama adalah untuk modal usaha dan memenuhi kebutuhan utama keluarga.

Di tingkat nasional, kesuksesan ASKA di wilayah urban diikuti juga di wilayah perdesaan terutama di Sulawesi Tengah, Sulawesi Tenggara dan Sulawesi Selatan serta Maluku Utara. Bagi petani kakao, yang bisa melakukan “panen kecil” setiap 2 minggu sekali, keikutsertaan masyarakat menjadi anggota kelompok ASKA ini sangat membantu pengelolaan uang hasil panen mereka. Hal tersebut dibuktikan dengan semakin tingginya jumlah anggota dan aset yang dikumpulkan di setiap kelompok.

\subsubsection{Kisah Nyata Manfaat Ikut Kelompok ASKA}

Tabung gas, modal usahaku bertambah karena meminjam di kelompok ASKA. - Pak Ismail adalah pengusaha mikro warung kelontong di rumah. Beliau juga menjual tabung gas ukuran $3 \mathrm{Kg}$, berjumlah 10 buah. Saat awal bergabung di kelompok ASKA Maju Bersama, beliau hanya membeli 1 saham per pertemuan, dengan harga Rp 20.000/saham. Melihat kemudahan dalam meminjam di kelompok, beliau mengupayakan untuk membeli 5 saham per pertemuan sehingga cukup untuk meminjam sebesar Rp 4.000.000,00 dan menggunakannya untuk membeli tabung gas sebanyak 40 buah. Jumlah tabung bertambah, maka perputaran uang dari penjualan gas juga bertambah dan cepat. Sampai saat ini, Pak Ismail telah mempunyai 100 tabung gas ukuran $3 \mathrm{Kg}$, sebagai modal usahanya dan beliau tetap setia menjadi anggota kelompok ASKA (Sumber: Laporan Tahunan, Area Development Program (ADP) Cawang, WVI, 2015). 
Pemasangan listrik biaya sendiri, kemandirian dalam PERT. - Ibu Kartini, seorang ibu rumah tangga warga RW 02 Makasar bergabung di kelompok ASKA Serumpun. Bu Kartini punya usaha membuat keripik bawang. Pekerjaan suami Bu Kartini sebagai buruh harian dengan penghasilan tidak menentu. Bersama suami dan ketiga anaknya, mereka tinggal di rumah yang mengandalkan listrik yang berasal dari mertua. Saat akhir siklus, ternyata tabungan Bu Kartini cukup untuk dipakai pemasangan instalasi listrik dari PLN di rumahnya. Pengalaman menabung dalam ASKA telah membuat Bu Kartini semakin terampil dan mandiri dalam pengelolaan ekonomi rumah tangganya.

Pertama pulang kampung dalam 43 tahun merantau,- Bapak Azis berprofesi sebagai kuli angkut di pelabuhan Kalibaru, Cilincing, Jakarta Utara. Berasal dari Lombok Barat, NTB, Pak Azis sudah merantau ke Jakarta sejak tahun 1973. Selama 40 tahun tinggal di Jakarta, Pak Azis tidak punya tabungan sehingga pulang kampung hanyalah sebuah impian. Sejak tahun 2012, Pak Azis bergabung di kelompok ASKA Mandiri. Pada setiap akhir siklus, saat uang tabungan dibagikan, terasa manfaatnya. Tahun 2016 Pak Azis bersama salah seorang anaknya dan satu orang cucu, berhasil pulang ke kampung halaman. Pulang kampung pertama sejak 43 tahun (Sumber: Learning Document, Urban Jakarta, WVI, 2015; wawancara 2017).

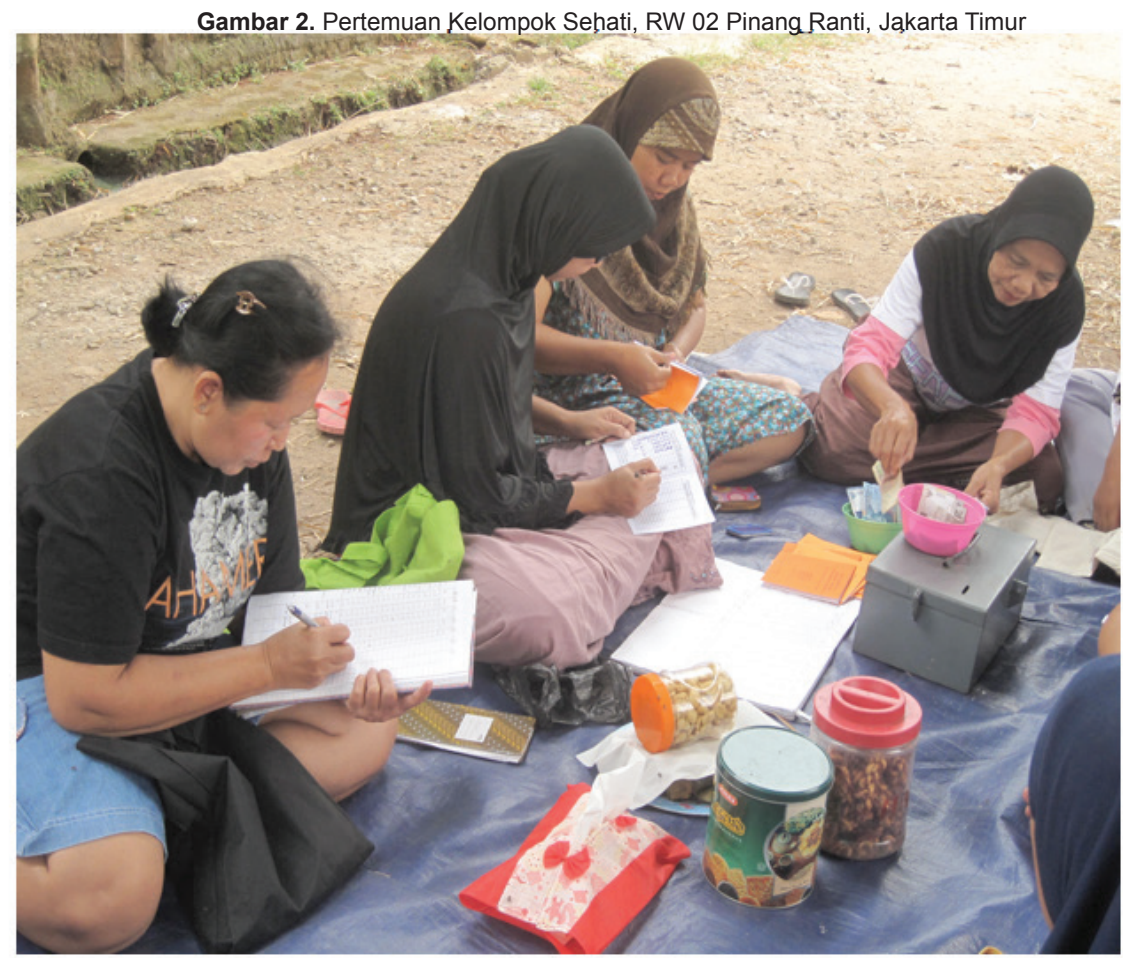




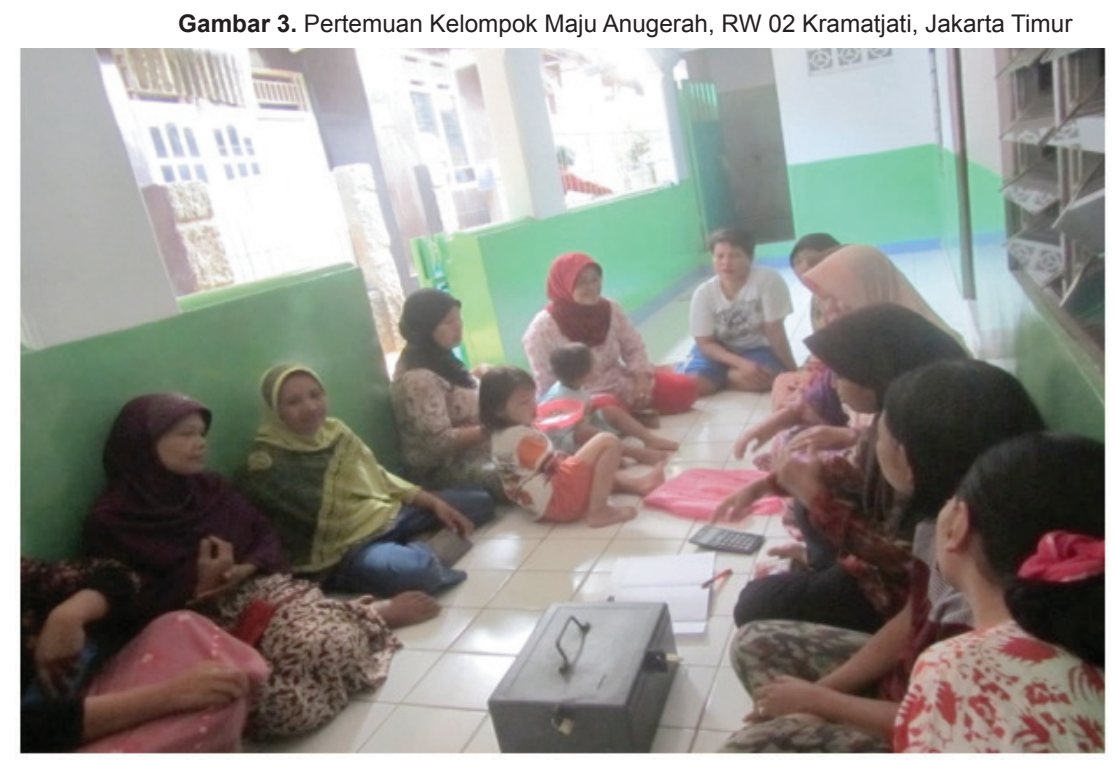

\subsection{Gambaran Pengelolaan Dana Sosial di Kelompok ASKA}

Kelompok simpan pinjam model ASKA juga juga mengembangkan solidaritas antar anggota dengan mengumpulkan dana sosial setiap pertemuan. Dengan nilai iuran antara Rp 2.000,00 - Rp 5.000/pertemuan. Dengan demikian dana sosial yang bisa dihimpun antara Rp 4.000,00 - Rp 10.000,00/bulan/anggota. Dana sosial merupakan santunan kepada anggota, bila ada anggota yang mengalami musibah (sakit atau kematian). Besaran dukungan/santunan kelompok kepada anggota yang mengalami musibah mencapai kisaran Rp 75.000,00 - Rp 150.000,00.

Kekurangan pengumpulan dana sosial di kelompok ASKA adalah pada pengelolaannya yang masih sendiri-sendiri di tiap kelompok sehingga dukungan/ santunan kepada anggota juga jumlahnya kecil sehingga belum bisa memenuhi kebutuhan anggota. Akan tetapi sebagai gerakan, inisiatif ini sudah memberi dampak berarti bagi anggota, bahwa sebagai masyarakat miskin dengan segala keterbatasan, ternyata bisa memberikan perlindungan satu dengan yang lain. Dengan demikian, inisiatif dana sosial sudah merupakan embrio, untuk masyarakat dapat mengakses sistem perlindungan sosial yang lebih besar yang dikembangkan lembaga asuransi.

\subsection{Aplikasi ASKA}

Salah satu kelemahan kelompok simpan pinjam non formal adalah kinerjanya tidak diakui oleh pihak di luar dirinya karena sistem pencatatan yang manual. Proses monitoring kinerja kelompok juga sulit dilakukan karena terjadi perubahan 
yang terus menerus dalam waktu yang singkat. Di lain pihak, anggota kelompok ASKA sudah aktif memanfaatkan perkembangan teknologi dan akses informasi. Pengetahuan dan ketrampilan ini dapat menjadi bekal untuk meningkatkan kinerja kelompok dan anggota.

Berdasarkan potensi tersebut maka upaya untuk mendukung transparansi kinerja kelompok dan membangun kemandirian, dikembangkan suatu ide pembuatan aplikasi berbasis android. Tawaran ide ini disambut oleh PT. Accenture yang melihat bahwa kelompok ASKA apabila sistem monitoringnya menggunakan aplikasi akan lebih transparan, lebih membangun kedisiplinan dan rekam jejak keuangan anggotanya. Oleh karenanya, mulai tahun 2016 PT Accenture mendedikasikan untuk mengembangkan aplikasinya secara pro bono.

Aplikasi ASKA sangat mudah digunakan (user friendly). Secara mandiri, pengelola kelompok dapat memasukkan seluruh transaksi keuangan yang terjadi di setiap pertemuan kelompok, sehingga secara real time anggota, pengurus dan pendamping kelompok dapat mengetahui hak dan kewajiban keuangannya.

Ada 3 pihak utama berinteraksi dalam Aplikasi ASKA yaitu.

1. Admin lembaga pendamping, dalam hal ini WVI;

2. Admin Kelompok, biasanya 2-3 orang dari pengelola per kelompok

3. Anggota Kelompok

Ketiga pihak inilah yang nomor telepon selulernya dimasukkan dalam aplikasi sehingga dapat berinteraksi.

Adapun fitur yang tersedia adalah

1. Tinjauan saya, fitur ini ada di anggota kelompok dan admin kelompok untuk melihat keseluruhan transaksi individual anggota dan seluruh anggota kelompok baik dana sosial, neraca maupun pinjaman.

2. Tinjauan kelompok saya, fitur ini ada untuk anggota kelompok dan admin kelompok untuk melihat seluruh transaksi anggota dan kinerja keuangan kelompok dalam setiap pertemuan.

3. Tinjauan semua kelompok, fitur ini hanya untuk admin lembaga pendamping (WVI), untuk melihat seluruh aktivitas kelompok yang sudah menggunakan aplikasi.

4. Buat transaksi, fitur ini hanya ada di admin kelompok, untuk memasukkan aktivitas kelompok mulai saat mendaftarkan semua anggota maupun transaksi keuangan di setiap pertemuan. 
5. Kelola keluhan/keluhan saya, fitur ini hanya ada di admin kelompok dan admin lembaga pendamping (WVI) untuk menyampaikan semua keluhan dan meresponnya.

6. Kelola semua kelompok / kelola kelompok saya, fitur ini ada di admin kelompok dan admin lembaga pendamping (WVI) untuk mengelola informasi dasar anggota dan informasi dasar kelompok serta status kelompok.

Pada tahun 2017, fitur ditambahkan dengan fitur demo, untuk memberi kesempatan banyak pihak mencoba menggunakan Aplikasi ASKA sampai terampil sehingga semakin banyak pihak memahami aplikasi ini dengan baik. Selain itu juga ditambahkan fitur offline. Fitur ini untuk mengantisipasi kelompok ASKA yang terkendala dengan akses internet. Dengan fitur ini maka kelompok dapat memasukkan transaksi secara offline dan segera setelah mendapatkan akses internet maka data segera bisa disinkronisasi.

Rencana pengembangan lebih lanjut adalah 1) Membuat silang pinjam antar kelompok, karena ada beberapa kelompok yang asetnya berlebih bila dibandingkan permintaan pinjaman anggota, sedangkan kelompok lain ada yang kekurangan dana pinjaman, 2) Menghubungkan Aplikasi ASKA dengan sistem informasi dari LKM formal (bank atau koperasi mitra) dan lembaga asuransi mitra, sehingga rekam jejak keuangan anggota yang baik bisa menjadi pengganti jaminan fisik, saat anggota membutuhkan akses keuangan yang lebih besar dan lebih baik.

Dengan demikian pada akhirnya, semakin banyak masyarakat miskin yang mendapat kemudahan mengakses dana dari LKM formal dan mengakses lembaga asuransi, berbekal rekam jejak keuangannya yang baik. 


\section{PERKEMBAИGAИ APGIKASI 20\%7}
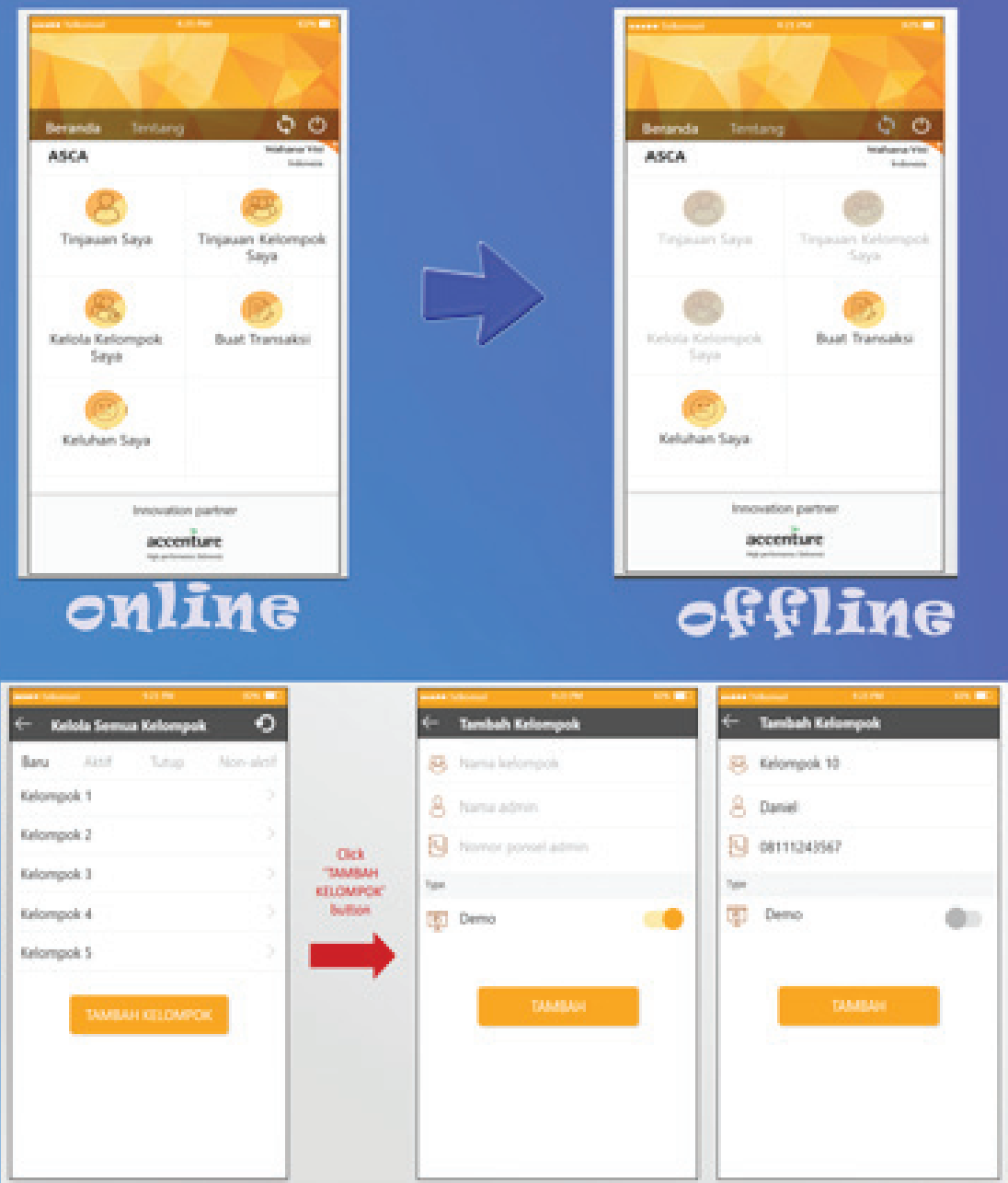

Sițdre lettihem/demo 


\section{Dampak Program}

\subsection{Membangun Sistem Kemandirian Masyarakat Miskin}

Berkaca dari keberhasilan pendekatan kelompok ASKA menunjukkan penanggulangan kemiskinan melalui keuangan mikro dapat dilakukan tanpa terlalu besar subsidi dari pihak di luar masyarakat miskin itu sendiri. Program keuangan inklusif sudah di praktekkan langsung dengan membangun tabungan dari aset yang terbatas. Hal ini disebabkan orang miskin bukanlah orang yang tidak mempunyai apa-apa, namun hanya mempunyai aset yang sedikit atau terbatas. Dengan mengumpulkan aset terbatas antar orang miskin dan melakukan kerjasama dengan mengembangkannya dalam pinjaman antar anggota, yang digunakan untuk akses modal ataupun untuk memenuhi kebutuhan utama, masyarakat telah dapat menolong dirinya sendiri. Yang dibutuhkan adalah pengorganisasian dan membangun sistem yang menarik dan memenuhi kebutuhan masyarakat miskin.

Model kelompok ASKA dapat dimanfaatkan sebagai strategi awal untuk proses belajar dari masyarakat miskin tentang pentingnya menabung, mengatur kedisiplinan dalam mengelola tabungan dan pinjaman dan mengubah perilaku dalam membelanjakan uang yang dikumpulkan antar mereka. Sedangkan nantinya LKM formal dan lembaga asuransi akan menjadi lembaga lanjutan yang akan diakses oleh masyarakat yang membutuhkan dana modal yang lebih besar dan dana tersebut sudah tidak dapat dipenuhi lagi oleh kelompok model ASKA, juga produk-produk asuransi yang lebih banyak memberikan perlindungan.

Dengan demikian pendekatan ASKA ini menjadi solusi yang efektif dan efisien serta berkelanjutan untuk upaya pengentasan kemiskinan karena program tidak melakukan distribusi namun melakukan perubahan perilaku. Tabel berikut menjelaskan masalah yang ditemui saat melakukan upaya pengentasan kemiskinan, solusi yang dijawab dengan pendekatan ASKA dan dampak atas kondisi tersebut. 
Tabel 1. Masalah, Solusi, dan Dampak

\begin{tabular}{|c|c|c|}
\hline Masalah & Solusi & Dampak \\
\hline $\begin{array}{l}\text { Masyarakat miskin rendah } \\
\text { diri dan tidak punya apa-apa }\end{array}$ & $\begin{array}{l}\text { Melakukan tabungan harian dari } \\
\text { penyisihan pendapatan. Tabungan } \\
\text { harian dibelikan saham saat pertemuan } \\
\text { kelompok. }\end{array}$ & $\begin{array}{l}\text { Dengan punya saham di kelompok, } \\
\text { kepercayaan diri masyarakat } \\
\text { miskin meningkat karena dirinya } \\
\text { berharga dan punya andil di } \\
\text { kelompok. }\end{array}$ \\
\hline $\begin{array}{l}\text { Masyarakat miskin selalu } \\
\text { harus dibantu dengan } \\
\text { bantuan sosial }\end{array}$ & $\begin{array}{l}\text { Di kelompok ASKA dikumpulkan dana } \\
\text { sosial secara rutin/pertemuan. Dana } \\
\text { sosial diberikan kepada anggota dan } \\
\text { keluarganya yang membutuhkan. }\end{array}$ & $\begin{array}{l}\text { Penghargaan diri masyarakat } \\
\text { miskin meningkat, karena dengan } \\
\text { melalui dana sosial di kelompok, } \\
\text { mereka dapat berbagi dan bukan } \\
\text { hanya menunggu pemberian. }\end{array}$ \\
\hline $\begin{array}{l}\text { Orang miskin tidak punya } \\
\text { uang untuk ditabung }\end{array}$ & $\begin{array}{l}\text { ASKA mendorong kebiasaan menabung } \\
\text { dari yang sedikit dengan tabungan } \\
\text { harian dan kewajiban membeli saham } \\
\text { di pertemuan. Nilai saham per anggota } \\
\text { yang semakin meningkat menjadi bukti } \\
\text { bahwa orang miskin bisa mempunyai } \\
\text { tabungan. }\end{array}$ & $\begin{array}{l}\text { Perubahan perilaku dari yang biasa } \\
\text { berhutang menjadi bisa menabung. } \\
\text { Perubahan ini didasari oleh } \\
\text { kesadaran dan kedisiplinan dan } \\
\text { bukan hanya untuk mendapatkan } \\
\text { kredit atau proyek kredit atau } \\
\text { bantuan tunai seperti sebelumnya, } \\
\text { dimana jumlah tabungan menjadi } \\
\text { semakin berkurang atau menjadi } \\
\text { nol. }\end{array}$ \\
\hline $\begin{array}{l}\text { Orang miskin sering tidak } \\
\text { bisa mengembalikan } \\
\text { pinjaman / kredit macet }\end{array}$ & $\begin{array}{l}\text { Pengaturan dari kelompok ASKA dimana } \\
\text { saham anggota adalah jaminan atas } \\
\text { pinjaman dirinya dengan nilai pinjaman } \\
\text { maksimal } 2 \text { kali sahamnya. }\end{array}$ & $\begin{array}{l}\text { Masyarakat miskin menjadi } \\
\text { disiplin memanfaatkan uang } \\
\text { pinjaman karena sadar bahwa uang } \\
\text { yang dipinjam adalah uangnya } \\
\text { sendiri dan bukan uang bantuan } \\
\text { atau proyek. }\end{array}$ \\
\hline $\begin{array}{l}\text { Usaha mikro tidak layak } \\
\text { mendapatkan pinjaman } \\
\text { karena tidak ada jaminan } \\
\text { atau administrasi berbelit }\end{array}$ & $\begin{array}{l}\text { Pinjaman dilakukan berdasarkan nilai } \\
\text { saham sendiri. Tidak ada administrasi } \\
\text { yang berbelit ataupun biaya administrasi. }\end{array}$ & $\begin{array}{l}\text { Usaha mikro di wilayah target } \\
\text { menjadi berkembang karena biaya } \\
\text { modal usaha anggota lebih murah } \\
\text { dan mudah }\end{array}$ \\
\hline $\begin{array}{l}\text { Orang miskin terbelit } \\
\text { renternir. }\end{array}$ & $\begin{array}{l}\text { Dalam ASKA hanya dibutuhkan } \\
\text { karakter orang yang baik sehingga } \\
\text { peminjaman uang untuk kebutuhan } \\
\text { mendesak ataupun modal usaha, mudah } \\
\text { didapatkan. }\end{array}$ & $\begin{array}{l}\text { Peran pelepas uang atau renternir } \\
\text { semakin mengecil. }\end{array}$ \\
\hline $\begin{array}{l}\text { Program kredit untuk orang } \\
\text { miskin, banyak yang macet }\end{array}$ & $\begin{array}{l}\text { Kelompok ASKA adalah kelompok } \\
\text { belajar untuk mengubah perilaku, yaitu } \\
\text { menjadi penabung aktif, peminjam aktif } \\
\text { dan mempunyai kohesi sosial yang baik. }\end{array}$ & $\begin{array}{l}\text { Karakter penabung dan peminjam } \\
\text { baik ini menjadi modal besar untuk } \\
\text { dapat menjadi calon nasabah LKM } \\
\text { formal. Program financial inclusion } \\
\text { pemerintah dapat terbantu. }\end{array}$ \\
\hline $\begin{array}{l}\text { Biaya program pengentasan } \\
\text { kemiskinan, melalui kredit } \\
\text { murah atau bantuan tunai, } \\
\text { sangat mahal }\end{array}$ & $\begin{array}{l}\text { Program ASKA terbukti hanya } \\
\text { membutuhkan investasi yang kecil } \\
\text { di tahun pertama saja, selanjutnya } \\
\text { masyarakat yang melakukan investasi } \\
\text { secara mandiri. Non Performance Loan } \\
(N P L) \text { nya nol. }\end{array}$ & $\begin{array}{l}\text { Investasi dilakukan dalam bentuk } \\
\text { penguatan kapasitas masyarakat. } \\
\text { Biaya investasi relatif lebih kecil } \\
\text { dibandingkan program kredit } \\
\text { murah ataupun bantuan tunai. }\end{array}$ \\
\hline $\begin{array}{l}\text { Orang miskin tidak bisa } \\
\text { mengorganisir dirinya sendiri }\end{array}$ & $\begin{array}{l}\text { Program ASKA mewajibkan kelompok } \\
\text { membuat aturan ketat untuk mengatur } \\
\text { kelompoknya sendiri, termasuk } \\
\text { pemberian denda. Pengelola berganti } \\
\text { dalam setiap tahun. }\end{array}$ & $\begin{array}{l}\text { Kelompok menjadi mandiri } \\
\text { dalam pengambilan keputusan } \\
\text { dan pengelolaan kelompok. } \\
\text { Kedisiplinan terbangun dan } \\
\text { kepemimpinan dalam kelompok } \\
\text { meningkat. }\end{array}$ \\
\hline $\begin{array}{l}\text { Orang miskin banyak yang } \\
\text { buta huruf, sulit bisa diajak } \\
\text { tulis menulis }\end{array}$ & $\begin{array}{l}\text { ASKA menggunakan media-media yang } \\
\text { mudah dipakai, bahkan oleh anggota } \\
\text { yang buta huruf. }\end{array}$ & $\begin{array}{l}\text { Semua orang miskin bisa menjadi } \\
\text { anggota kelompok ASKA. Baik } \\
\text { dewasa maupun anak-anak, baik } \\
\text { laki-laki ataupun perempuan. }\end{array}$ \\
\hline $\begin{array}{l}\text { Kelompok simpan pinjam } \\
\text { tidak aman, karena banyak } \\
\text { disalahgunakan pengurus } \\
\text { atau anggota }\end{array}$ & $\begin{array}{l}\text { Penggunaan kotak besi berkunci tiga } \\
\text { dan hanya bisa dibuka saat pertemuan } \\
\text { menjadikan pengelolaan kelompok } \\
\text { menjadi transparan. }\end{array}$ & $\begin{array}{l}\text { Kepercayaan meningkat dan yakin } \\
\text { bahwa uang anggota tidak hilang / } \\
\text { tercuri / dibawa lari. }\end{array}$ \\
\hline
\end{tabular}




\subsection{Aplikasi ASKA - Membangun sistem informasi dan monitoring berbasis masyarakat}

Dampak dari pemanfaatan Aplikasi ASKA oleh semakin banyak anggota kelompok ASKA adalah

1. Bagi anggota kelompok: memudahkan anggota untuk mengetahui aset dan kewajibannya terhadap kelompok. Keterbukaan dan solidaritas juga semakin kuat karena anggota dapat saling melihat rekam jejak keuangan sesama anggota. Prinsip transparansi ini menjadi salah satu prinsip yang dihidupi kelompok ASKA. Anggota juga secara langsung sudah membangun rekam jejak keuangan anggota sehingga bisa nantinya bisa menjadi dasar untuk pengganti jaminan fisik untuk akses ke LKM formal.

2. Bagi kelompok ASKA: memudahkan pengelola kelompok untuk memonitor kinerja keuangan kelompoknya dan rekam jejak keuangan anggota. Data kinerja kelompok juga dapat menjadi alat untuk melakukan advokasi bagi kelompoknya untuk mendapatkan akses informasi, penguatan kapasitas maupun akses dana kepada pihak lain (program pemerintah, swasta maupun pihak-pihak lainnya).

3. Bagi lembaga pendamping : memudahkan memonitor kinerja maupun masalah yang dihadapi kelompok sehingga mempercepat penyelesaian masalah. Praktek baik ini juga dapat digunakan sebagai contoh untuk dapat direplikasi di wilayah lainnya.

4. Bagi pemerintah (daerah/desa/kelurahan): memudahkan pemerintah dalam mendapatkan informasi tentang kinerja kelompok yang baik sehingga kelompok akan menjadi mitra utama pemerintah dalam melaksanakan program-program pengentasan kemiskinan maupun financial inclusion.

5. Bagi developer IT: aplikasi ini adalah "aplikasi yang hidup" sehingga terbuka kesempatan untuk mengembangkan fitur-fitur tambahan untuk mengatasi masalah yang ditemui. Dengan semakin banyak jumlah anggota yang menggunakan aplikasi ini maka dapat menjadi ajang promosi bagi developer.

6. Bagi LKM formal maupun perusahaan asuransi: dapat memberikan informasi calon nasabah / klien yang telah terbukti rekam jejak keuangannya baik. Dengan demikian aplikasi ini dapat menjadi salah satu alat manajemen resiko.

7. Bagi lembaga swasta: keterlibatan untuk mendukung penyebarluasan aplikasi ASKA, dapat menjadi salah satu program corporate social responsibility (CSR) dengan input kecil dan hasil besar karena model kelompok ASKA sudah terbukti 
memberi dampak bagi pembangunan karakter dan juga mendukung program pemerintah.

\section{Kesimpulan}

Kemiskinan di Indonesia sampai semester II 2017 masih mencapai 10,12\% (BPS, 2018) dan penduduk yang mempunyai akses ke sistem keuangan formal baru mencapai 52\% dari total penduduk, 31\% akses pada keuangan informal dan $17 \%$ penduduk mengalami ekslusifitas tidak mengakses sistem keuangan.

Pada kondisi miskin, seseorang yang tidak mempunyai akses pada sistem keuangan akan sulit untuk mendapatkan kesempatan untuk membangun tabungan, mengembangkan uangnya, mendapat resiko kehilangan dan tidak mempunyai dana cadangan saat terjadi resiko kehidupan.

Sektor keuangan dipercaya mempunyai peran penting dalam pengentasan kemiskinan, mengurangi perbedaan pendapatan dan meningkatkan pertumbuhan ekonomi. Untuk itu pemerintah menjadikan financial inclusion sebagai salah satu strategi untuk pengentasan kemiskinan dan peningkatan akses kepada lembaga keuangan, diantaranya melalui mekanisme pemberian langsung tunai maupun pemberian kredit murah. Keberlanjutan tabungan tidak terjadi karena uang dari luar diri masyarakat dan tidak terbangun kesadaran.

Pendekatan berlandaskan tabungan ditawarkan untuk meningkatkan program financial inclusion. Menggunakan model lembaga keuangan non bank yang telah ada, berkembang dan dipercaya masyarakat menjadi ide dasar untuk meningkatkan kemampuan menabung masyarakat dan peningkatan pendapatan dari masyarakat miskin. Model tersebut adalah kelompok simpan pinjam model ASKA (Asosiasi Simpan pinjam untuk Kesejahteraan Anak).

Model ASKA, dikembangkan dengan mengadopsi model ASCA (Accumulating Saving and Credit Assosiation), model yang dikembangkan oleh VSL Assosiates. Dengan menggunakan kotak besi berkunci 3, pertemuan rutin dalam jangka pendek, pengaturan kedisiplinan dalam menabung, berhutang dan pengelolaan kelompok menjadikan model ini berkembang dan dipercaya masayarakat. Dalam 6 tahun masa pendampingan oleh WVI, di Jakarta Utara dan Timur saja, jumlah kelompok berkembang dari 5 kelompok menjadi 66 kelompok dengan anggota mencapai 1.438 orang. Total dana yang ditabung anggota adalah Rp 2.586 juta dan telah berkembang menjadi Rp 3.010 juta. Secara nasional 
perkembangan jumlah kelompok dari 2015, 2016 dan 2017 adalah 60, 94 dan 122 kelompok dengan jumlah anggota meningkat dari 1.214 orang; 2.179 orang dan 2.614 orang; nilai tabungan masyakat miskin berturut-turut adalah 7.935 meningkat menjadi 111.729 dan meningkat menjadi 138.814 US\$ per tahun.

Kelompok model ASKA dimanfaatkan sebagai sarana belajar dari masyarakat miskin tentang pentingnya menabung, mengatur kedisiplinan dalam mengelola tabungan dan pinjaman dan mengubah perilaku membelanjakan uang yang dikumpulkan antar mereka.

Aplikasi ASKA dibangun untuk memudahkan pencatatan rekam jejak keuangan anggota ASKA maupun kinerja keuangan kelompok ASKA. Rekam jejak/ kinerja ini dapat dimanfaatkan sebagai sumber informasi bagi LKM formal (bank atau non bank) maupun lembaga asuransi sebagai data dasar untuk seleksi calon nasabah atau klien. Dengan demikian semakin banyak anggota ASKA yang menggunakan Aplikasi ASKA dan nantinya akan dapat mengakses sumber dana dari LKM bank (misalnya) dan mendukung program pemerintah dalam pengentasan kemiskinan maupun memperluas financial inclusion.

\section{Referensi}

Antara, Kantor Berita. (2016). Realisasi KUR hingga April Rp 31 Triliun. http:// www.antaranews.com/berita/555923/realisasi-kur-hingga-april-rp31-triliun. Diunduh pada 27 Juli 2016

Berita Jakarta. 2015. Pengurus Koperasi Jasa Keuangan akan Diberi Penghargaan. http://www.beritajakarta.com/read/19724/25-Pengurus-Koperasi-Jasa-Keuangan-akan-Diberi-Penghargaan\#.V5g8nRKt4ww . Diunduh pada 27 Juli 2016

Doi. Yoko. 2014. Keterlibatan Sektor Keuangan, Pengentasan Kemiskinan dan Pertumbuhan Ekonomi (Editorial Opini). http://web.worldbank.org/WBSITE/EXTERNAL/COUNTRIES/EASTASIAPACIFICEXT/INDONESIAINBAHASAEXTN/0, contentMDK:22806505 pagePK:1497618 piPK:217854 theSitePK:447244,00.html. Diunduh pada 26 Juli 2016.

Indonesia, Wahana Visi (WVI). (2015). Laporan Tahunan FY 2015 Area Development Program (ADP) Cawang. Tidak diterbitkan.

Indonesia, Wahana Visi (WVI). (2015). Learning Document Urban Jakarta 2015. Tidak diterbitkan.

Indonesia, Wahana Visi (WVI). (2016). Data Monitoring Kelompok ASKA 2016. Tidak diterbitkan.

Indonesia, Wahana Visi (WVI). (2018). Annual report FY 2017. Tidak diterbitkan. Kemiskinan, Tim Nasional Percepatan Penanggulangan (TNP2K). 2014. Warga Miskin Terakses Bank, 25 Persen Penerima Bantuan Menabung. 
http://www.tnp2k.go.id/id/artikel/warga-miskin-terakses-bank-25-persen-penerima-bantuan-menabung. Diunduh pada 26 Juli 2016.

Rakhmindyarto dan Syaifullah. 2014. Keuangan Inklusif dan Pengentasan Kemiskinan. http://www.kemenkeu.go.id/en/node/42978, diunduh pada 26 Juli 2016.

Statistik, Badan Pusat (BPS). (2016). Persentase Penduduk Miskin Maret 2016 Mencapai 10,86 Persen. https://www.bps.go.id/Brs/view/id/1229. Diunduh pada 27 Juli 2016

Statistik, Badan Pusat (BPS). (2018). https:/www.bps.go.id/linkTabelStatis/view/ id/1494. Diunduh pada 21 Juni 2018.

www.vsla.net 